\title{
The Degree at Which Administrative Leaderships in Tafila Technical University Practice the Requirements of Organizational Excellence from the Perspective of the Faculty Members
}

\author{
Mohammad Salem Al-Amarat ${ }^{1, *}$ \\ ${ }^{1}$ Department of Educational Psychology, Faculty of Educational Sciences, Tafila Technical University, Jordan \\ *Correspondence: Department of Educational Psychology, Faculty of Educational Sciences, Tafila Technical \\ University, Jordan. E-mail: Moh57_jo@yahoo.com
}

Received: April 9, 2019

Accepted: May 18, 2019 Online Published: June 5, 2019

doi:10.5430/wje.v9n3p9

URL: https://doi.org/10.5430/wje.v9n3p9

\begin{abstract}
This study aimed at identifying the degree at which administrative leaderships in Tafila Technical University practice the requirements of organizational excellence from the perspective of the faculty members. The researcher used the descriptive approach as well as the questionnaire for data collection, after verifying its validity and reliability. The study sample consisted of (107) faculty members. The results showed that the degree at which administrative leaderships in the University practice the requirements of organizational excellence was medium, with a mean of (2.71). the results also revealed that there are statistically significant differences at $(\alpha \leq 0.05)$ due to the variable of faculty in favor of the humanitarian faculties, while there are no statistically significant differences at $(\alpha \leq 0.05)$ due to the variables of academic rank and years of experience. In the light of the results, the study recommended a number of recommendations.
\end{abstract}

Keywords: organizational excellence, administrative leaderships, the faculty members, Tafila Technical University

\section{Introduction}

The tendency towards achieving excellence and quality in all the institutions, including higher studies institutions became an inevitable element in terms of gaining the highest levels of quality; it represents a response to the cultural, political, social and technical changes imposed by globalization as well as international competition.

Excellence management is one of the modern concepts which adds to a list of many other terms defined by the administrative thought and gained a high position in institutions' theory. It is considered as philosophy which emerged as a results of the appearance of organizations which aimed at finding the best ways to promote the performance and development of institutions in order to reach levels that satisfy the different stakeholders in the organization, such as the European Foundation for Quality Management (EFQM), The Malcolm Baldrige National Quality Award(MBNQA), as well as Deming Prize for quality in Japan (Rasheed, 2004).

Therefore, the higher studies institutions, including universities aim at achieving the competitive excellence regularly by having excellence in the outcomes related to their teaching, scientific research and community service as well as attempting to enhance the added value from the perspective of partners and stakeholders. The strategy of excellence requires connecting the potentials and capabilities of the university with the added value targeted among stakeholders (Shawwa, 2016).

The human potentials and capabilities are considered as the most important factor in order to achieve the desired objectives of institutions; their importance lies in their influential role in raising the institution's efficacy in performing its tasks and activities (Hassan, 2010). This requires the existence of qualified leadership with prospective vision towards the future in order to contribute to creating a comprehensive development in the cultural, cognitive, research and societal domains, enhance the culture of excellence, focus on setting the strategies, update the organizational structures, change the traditional systems, develop the existing competencies, attract them and invest them (Al-Hadi, 2013).

The effective investment for competencies gives the institutions the ability to compete and achieve excellence. This 
investment is best reflected by managing competencies, where the competencies in this era represent a valuable human source and capital. This, indeed, made competencies management, employees appointment as well as discovering and developing their talents as the most prominent priorities of an institution. The Japanese, German, Korean, Chinese and the Malaysian experiments as well as others confirm this view (Hamidi \& Tayib, 2011).

Harshah and Zoraiqat (2013) as well as Khairi, (2014) suggested that organizational excellence aims at connecting the institution's strategies in the different administrative levels in order to achieve positive outcomes through distinctive initiatives as well as the contribution to administrating organizational change by transferring from the current situation in the institution to a better situation, capable of competition and innovation, disseminating the best practices, promoting the spirit of responsibility among employees, in addition to achieving the effective organizational communication in all the directions among all the elements and levels in a manner that improves the levels of performance.

Organizational excellence has an important role in achieving continuity, success and excellence for institutions, achieving high profits, attracting customers and enhancing their loyalty through a thorough understanding for the concept of their internal processes (creativity, operation, as well as social interaction) in the frame of quality and employees' efforts in giving solutions for the problems that face their institutions (Kasasbeh, 2011).

Dala'ein (2010) indicated that organizational excellence gives institutions the ability to contribute in a strategic way via their superiority in performance and problem-solving, and then achieve their objectives in an effective way that distinguishes them from other institutions. He also suggested that possessing and activating organizational excellence is the best way for their maintenance and continuity in the recent time which is based on rapid movement as well as regular change.

Organizational excellence management is the outcome of applying a set of criteria that enable the institution to reach unprecedented competitive results (Ja'bari, 2004). There is a set of basic pillars for achieving excellence in performance which are represented by the clear vision and message for the institution, constructing an effective role for leadership in senior management, putting the right man in the right place, efficacy and competency in the procedures of the institution's business as well as responding to the changes that take place and cope with the developments (Aasi, 2014).

Grote (2002) indicated that there are several limitations for achieving organizational excellence represented by: the existence of a leadership with vision in institutions that empower the employees working in them. He also suggested that these institutions should always focus on the future, activate the role of knowledge and activate the organizational learning as well as the individual learning.

Shin, Kalinowski and Abu El-Enein (1998) indicated that the requirements of organizational excellence in universities are related to the existence of a complete strategic structure that expresses the main trends, as well as future vision of the institution; it includes the university vision, message and the strategic objectives that it aims to achieve. They also confirmed the necessity of creating a flexible organizational structure that is consistent with the requirement of performance, which is capable of modification and adaptation with the internal and external changes, providing a developed system to manage the human resources, in addition to creating an effective leadership that sets the criteria and providing the appropriate application pillars for plans and programs.

Hence, excellence requires a continuous effort as well as technical administrative directions at work in order to build an organizational culture in the institutions that supports excellence and creativity. Therefore, there have been several Arabic and international models for distinctive performance, such as the European model, the Japanese model, the American model and the Jordanian model, which aims to improve performance in all the work aspect in order to promote the level of the total organizational performance, where the element of excellence is considered as one of the modern administrative elements which aims at improving the efficacy of educational institutions and increasing their capabilities to face the surrounding changes by satisfying the requirements of the beneficiaries and improving the quality of the provided service (Dawoud, 2002).

The domains related to organizational excellence in universities include the domain of attracting academic competencies, which represents an activity that is interested in identifying the sources of workers, and attracting them and searching for the most suitable candidate to occupy a certain job. The process is not only limited to attracting those having the required qualifications and abilities for the job, but also expands to include their motives, ambitions and interests (Hijazi, 2014). The process of attraction aims at determining the numbers and the required qualities of employees, providing the sufficient number of suitable applicants to occupy the needed jobs at the lowest possible costs, promoting the selection process by focusing on attracting the right people selected for the jobs; and 
thus reducing the number of non-qualified applicants to the required jobs, as well as increasing the efficiency of the institution by increasing the rates of employment stability and creating a highly qualified workforce (Saleh \& Salem, 2006).

The process of attraction contributes to achieving the social, legal, and ethical responsibility by preserving the rights of the human resources selected for the jobs available in the institution and contributing to the stability of human resources by attracting qualified candidates and retaining the desired human resources in the institution (Mustafa, 2011).

Therefore, the researcher suggests that the institution which has efficient human resources management will also have effective outcomes, where the institution's success is closely related to the successful human resources management through their practices, such as planning for human resources, attracting them, selecting them, recruiting them, training and developing them, as well as evaluating their performance, maintaining them and setting an unbiased program for incentives and rewards.

The other domains related to the requirements of organizational excellence for administrative leadership at universities are: the domain of creative leadership, where leadership has a direct impact on excellence by developing the individuals' capabilities and encouraging them to step towards innovation and excellence, through its characteristics related to leadership skills and effective work relationships, the ability to creative thinking that moves away from tradition, as well as its interest in encouraging competition among individuals in order to come up with new ideas. The senior leadership also adopted the open-door strategy as well as supporting direct communication between it and other individuals in the institution which would, in turn, allow for exchanging the information related to the effectiveness of the institution, the ability to discuss it, agreeing about suggestions and creating of new solutions to problems (Shawwa, 2016).

There are a number of activities that leaders should do in order to promote excellence in the institution. The decentralized system of work within the organization facilitates the direct flow of information as well as creative ideas between the staff and senior leadership without bureaucratic barriers and the creative ability of individuals is influenced by the pattern of democratic leadership. The distinctive leader who can observe many problems within a certain situation has the ability to underscore mistakes and shortcomings and deal with these problems. Undoubtedly, people who are sensitive to problems and shortcomings in all the situations have more opportunity to make more research and inquiry about them; if they did so, they would be likely to reach more excellence (Sa'eed, 2013).

Shawwa (2016) indicate that distinctive university leaderships are characterized by many characteristics, such as the creative vision based on conceptualizing the multiple alternatives to deal with the existing problems, the ability to raise the appropriate and right questions, confidence with self and others, doesn't give up easily, excepts failure at any stage, but doesn't surrender, has the ability to deal with change requirements, can deal with the difficult situations since they urge it to do more and find alternative solutions, gas the ability to adapt, try and change, has power to give its opinion and provide suggestions, enjoys individual autonomy, doesn't allow others to impose their power on it or vice versa, and keeps itself away from morale inhibitors among university attendants.

As for the domain of job succession, refers to finding the suitable and alternative person who can replace the actual employee when he is absent in order not to let the job position empty.

The job succession lies in determining the qualified and skilled employees who seek to reach promotion and leadership levels. The institution provides those with training opportunities, increase their awareness in order to prepare them to occupy the leadership responsibilities in the future, in addition to attracting those with distinctive potentials to the institution and retaining them by creating common tasks between planning the human resources and job succession. When institutions do the appropriate planning for leaderships, this would contribute to achieving employees' commitment with performance as well as their maintenance in the institution (Harrison, McKinnon, \& Terry, 2006).

The ineffective planning for leadership succession leads the institutions to face considerable challenges in doing that and satisfying their customers due to not assigning the right person in the right place (Ward, 2000).The researcher addressed the dimension related to retaining the academic qualifications, where all the universities seek to do their effort in order to encourage and motivate the academics, particularly the distinguished ones. This contributes to their maintenance in their work at the institution and ensures its success which is achieved through the committed and loyal workforce for the institution (Homoud \& Sheikh, 2013).

The most important factors affecting the universities maintenance with the academic qualifications are: the academics relationship with the administration, the availability of professional growth opportunities and developing 
new practices as well as the tasks that include meaningful challenges. The process of academic qualifications maintenance contributes to reducing expenses, where the cost of academic qualifications maintenance is less than the cost of looking for them, discovering and attracting them, retaining investment in human resources, especially the qualified ones, reducing the rate of circulation of the qualified academics, in addition to the continuity of the institution's success, excellence and increased productivity (Hamdan, 2014).

Universities can maintain academic qualifications by providing a socially and psychologically attractive environment since such an environment has a considerable impact on the work of academic qualifications and the efficacy of their performance, in addition to using the various motivation methods and planning the career path in order to achieve job security and satisfaction for academics, providing a technologically-equipped environment as well as a comfortable place for work and reduce work stressors, in addition making advantage of the developed universities experiences in terms of maintaining academic qualifications (Hareem, 2013)

Several studies were conducted in the field of organizational excellence, including Al-Ghamidi (2018) which aimed at identifying the extent of organizational excellence among the female school managers in the region of Albaha from the perspective of teachers. The researcher used the descriptive survey approach. The study population consisted of (4146) female teachers and the study sample consisted of (345) female teachers. The questionnaire was used as a tool for data collection. The results revealed that the degree of practicing organizational excellence among the female school managers in the region of Albaha was high. The results revealed that there are statistically significant differences at $(\alpha \leq 0.05)$ according to the variable of educational stage in favor of the middle stage, and for the educational qualification in favor of the post graduate group.

Domour (2017) conducted a study which aimed at detecting the relationship between strategic fitness and organizational excellence among academic leaders in the Jordanian universities from the perspectives of the faculty members. The researcher used the descriptive approach. The study sample consisted of (470) individuals. The questionnaire was used as a tool for data collection. The results revealed that the degree of practicing organizational excellence among the academic leaders in the Jordanian universities was low. The results also revealed that there were statistically significant differences according to the variable of faculty in favor of the human faculties, while there were no statistically significant differences attributed to the variable of academic rank and years of experience.

Daradkeh (2017) conducted a study which aimed at identifying the level of administrative empowerment and organizational excellence among academic leaders in Ta'if University from the perspectives of the faculty members. The researcher used the analytical descriptive approach and the questionnaire was used as a tool for data collection. The study sample consisted of (331) faculty members. The results revealed the results revealed that the degree of practicing organizational excellence among the academic leaders from the perspectives of the faculty members was medium. The results also revealed that there were no statistically significant differences between the mean scores of the faculty members in their estimation for the degree of practicing organizational excellence among the academic leaders due to the variables of gender, faculty, academic rank, and years of experience.

Qawasmeh and Bourini (2016) conducted a study which aimed at identifying the level of practicing university excellence management at Gadara University from the perspective of employees and students using the European model for excellence. The researchers used a questionnaire that consisted of (50) items for data collection. The study sample consisted of (345) employees and students. The results showed that the level of organizational excellence in Gadara University was medium. The results revealed that there were statistically significant differences according to the variable of job in favor of the employees in the university, while there were no statistically significant differences according to the variable of gender.

Nuwiqeh (2014) conducted a study which aimed at identifying the impact of empowerment on achieving organizational excellence using an applied study for the conceptualizations of work teams members in Al-Ta'if university with a total of (19) teams. The researcher used the descriptive approach and the questionnaire was used as a tool for data collection, it was distributed to the sample individuals, and (110) questionnaires were returned. The results concluded a number of results, including that there is a high level of organizational excellence.

Dehaghani and Pourtaher, (2014) conducted a study which aimed at detecting the impact of organizational commitment and organizational excellence among academic leaders in Yasouj University for medical sciences in Iran. The researcher used the descriptive approach as well as a questionnaire for data collection. The study sample consisted of (294) employees working at the university. The results revealed that when the manager evaluates the career tasks and duties if the employees, they will be more interested in their work; therefore, their performance will be distinguished and eventually reflected on the organization's excellence. 
Shehada and Hourani (2014) conducted a study which aimed at analyzing the attitudes of faculty members working at the University of Jordan towards the proposed standards for evaluating the academic excellence. The questionnaire was used for data collection and applied to a sample of (174) faculty members. The study results showed that there is a strong tendency among faculty members to link teaching excellence with active learning, and the faculty members also have a strong tendency to link excellence in scientific research with their participation in research teams as well as conducting comprehensive research surpassing the narrow disciplines. The study results also showed that there is a strong tendency among faculty members to link excellence in teaching with the degree of using technology.

Majeed (2010) conducted a study which aimed at identifying the impact of knowledge management on organizational excellence from the perspective of administrative staff in the private Jordanian universities in the middle region of Jordan. The questionnaire was used as a tool for data collection. The study sample consisted of (546) individuals. The results revealed that the employees conceptualizations for organizational excellence were high. The results revealed that there are statistically significant differences at $(\alpha \leq 0.05)$ according to the variables of educational experience and experience.

Teay (2003) conducted a study which aimed at building a model for measuring the distinguished performance in management at universities. This model was based on quality management model for Baldrige and Malcolm in assessing performance and specific quality. The proposed model was used at the level of management and faculty members with the aim of regular improvement and as an indicator for the different types of management and faculty members in universities. The study was applied to a sample of four faculties. The results led to setting a model for constructing excellence related to the quality in university education which consists of the following criteria: leadership, strategic planning, results, customers, focusing on the market, the process of management and human resources, as well as information and analysis. The results showed that it is possible to use the proposed model to measure the performance of the faculty member, management and university in order to determine the main performance indices as well as the final impact on the development related to excellence and specific quality in performance.

The researcher made advantage of the previous studies in identifying organizational excellence; interpreting the study results; preparing the tool used in the current study; citing the study problem, questions and objectives; citing the study methodology; determining the study variables as well as determining the statistical methods that are appropriate for processing the data of the current study.

\subsection{The Study Statement}

The general manager of scientific research support fund in Jordan confirmed that the classification of the Jordanian universities witnesses an increasing decline since 1996 and that none of the national universities gained a position in the range of the best 500 universities at the international level according to (QS) classification. Also, none of them approached the rank (750) according to Shanghai and Times classification. Additionally, none of the Jordanian universities approached the rank (750) according to the international classification the universities (Zo'bi, 2016). According to Web metrics classification (2018), the university of Jordan was in the first rank locally, in the $10^{\text {th }}$ rank at the Arab World level, and in the rank (1201) at the international level amongst (27000) universities included in that version (Bakir, 2018).

Some studies also recommended conducting more researches about organizational excellence, such as (Al-Ghamidi, 2018) and (Dararkeh, 2016). In the same vein, Nuwiqeh (2014) recommended searching for new methods and opportunities to achieve organizational excellence at universities die to the importance of that in attaining their strategic objectives. Additionally, the researcher pointed out that there are shortcomings and obstacles in achieving organizational excellence in universities as well as a lack in the competencies in some leadership positions at universities.

Therefore, this study was conducted with the aim of detecting the degree at which administrative leaderships in Tafila Technical University practice the requirements of organizational excellence by answering the following questions:

1. What is the degree at which administrative leaderships in Tafila Technical University practice the requirements of organizational excellence from the perspective of the faculty members?

2. Are there are statistically significant differences at $(\alpha \leq 0.05)$ regarding the study sample individuals estimation for the degree at which administrative leaderships in Tafila Technical University practice the requirements of organizational excellence according to the variables of (faculty, academic rank, years of experience)? 


\subsection{The Study Objective}

Identifying the degree at which administrative leaderships in Tafila Technical University practice the requirements of organizational excellence.

\subsection{The Study Importance}

The study importance lies in the following:

1. It addressed one of the issues that touch the essence of the educational institutions, which is excellence since those institutions operates in an increasingly developing environment and the response to this development is a necessity.

2. Based on the researcher's acquaintance on the resources related to the study, it is evident that the current study would be one of the first field attempts in Tafila university which aims at detecting the degree at which administrative leaderships in Tafila Technical University practice the requirements of organizational excellence.

3. This study could enrich the theoretical and scientific side of the researcher which would be reflected on the occupational and professional domains of his performance.

4. The researcher hopes that the results of the current study will provide the university administration with a feedback about its level of organizational excellence. Therefore, it would promote the strengths and address the weaknesses.

\subsection{The Study Terminology}

The study addressed the following terms:

- Organizational excellence: it is a state of administrative innovation and organizational superiority that achieves high levels of performance and implementation for the productive, financial and marketing processes as well as others, in a manner that results in outcomes and achievements that surpass those achieved by other competitors and satisfy the customers and stakeholders in the institution (Salmi, 2002, p. 77).

It is procedurally defined as the total degree that the respondent achieves for his/ her response to the study tool that the researcher prepared for this study.

- Administrative leaderships: In this study they are the head of the university, the Vice Chancellor for Academic and Administrative Affairs, the Assistant President for Legal Affairs, as well as the deans of faculties.

\subsection{The Study Limits}

The study was limited with the following limits:

- The objective limit: the degree at which administrative leaderships in Tafila Technical University practice the requirements of organizational excellence from the perspective of the faculty members.

- The spatial limit: Tafila Technical University in the south of Jordan.

- The temporal limit: The first semester of the academic year 2018/2019.

- The human limit: the faculty members in Tafila Technical University in the south of Jordan.

\section{The Study Methodology}

The researcher used the descriptive approach due to its compatibility to the study nature.

\subsection{The Study Population}

The study population consisted of all the faculty members in Tafila Technical University with a total of (240) faculty member according to the statistics of the human resources department in the university (Tafila Technical University, 2018).

\subsection{The Study Sample}

The study sample consisted of (120) faculty members representing (50\%) of the study population. The questionnaire was applied to the sample individuals and (107) questionnaires were returned with a return percentage of $(89.2 \%)$ of the valid questionnaires. Table (1) shows the distribution of the sample individuals. 
Table 1. The Study Sample

\begin{tabular}{llcc}
\hline The variable & Category & Number & Percentage \\
\hline Academic rank & Associate professor or above & 46 & $43 \%$ \\
& Assistant professor or less & 61 & $57 \%$ \\
& Total & 107 & $100 \%$ \\
Faculty & Scientific faculties & 63 & $58.9 \%$ \\
& Humanitarian faculties & 44 & $41.1 \%$ \\
Years of experience & Total & 53 & $100 \%$ \\
& Less than 10 years & 32 & $49.5 \%$ \\
& 10-15 years & $22.9 \%$ \\
& More than 15 years & 107 & $20.6 \%$ \\
& Total & & $100 \%$ \\
\hline
\end{tabular}

\subsection{The Study instrument}

A questionnaire was developed as the study tool based on the theoretical literature and the related studies such as (Al-Ghamidi, 2018), (Dararkeh, 2016) and Majeed (2010). The questionnaire consisted of two parts:

- The first part: consisted of the demographic data including (faculty, academic rank, and years of experience).

- The second part: the domain of organizational excellence as follows:

1- The domain of creative leadership

2- The domain of attracting the scientific qualifications

3- The domain of job succession

4- The domain of Academic competency retention.

The domains were rated based on 5-point Likert scale (very high, high, medium, low, and very low).

\subsection{Validity of Instrument}

The apparent validity of the tool was verified by introducing it to a number of arbitrators in the field of leadership and educational administration and asking them to give their opinion about the study tool in terms of the number of items, their affiliation for the domains, and the suitability of citation, in addition to any deletion, modification or addition. The notices of arbitrators were taken into consideration in terms of paraphrasing some items and correcting some mistakes I them.

\subsection{Reliability of Instrument}

Reliability was calculated using internal consistency coefficient (Cronbach alpha), where the reliability coefficient was (0.94), which is a high value indicating the possibility to use the tool for collecting data.

\subsection{The Study Variables}

The study addressed the following variables:

The demographic variables, which includes:

* The faculty: the scientific faculties and the humanitarian faculties.

* Academic rank: associate professor or above, assistant professor or less.

* Years of experience: less than 10 years, (10-15) years, more than 15 years.

The independent variable: the degree at which administrative leaderships in Tafila Technical University practice the requirements of organizational excellence.

\subsection{The Statistical Processing}

The researcher used the statistical processing and methods in order to answer the study questions using (SPSS), these are:

* The means and standard deviations.

* T-tests.

* One-way analysis of variance. 


\subsection{The Study Scale}

The degree of agreement was determined based on the mean value according to the cut-off scores for the study tool scale using the following criterion:

* The mean value 1 - less than 1.80 , very low.

* The mean value $1.80-2.60$, low.

* The mean value $2.60-3.40$, medium.

* The mean value $3.40-4.20$, high.

* The mean value $4.20-5.00$, very high.

\section{The Study Results and Their Discussion.}

\subsection{The Results of the First Question}

Which states: What is the degree at which administrative leaderships in Tafila Technical University practice the requirements of organizational excellence from the perspective of the faculty members?

In order to answer this question, the researcher calculated the means and standard deviations for the domains of the study tool as illustrated in table (2).

Table 2. The Means and Standard Deviations for the Domains of the Study Tool

\begin{tabular}{llccll}
\hline Number & \multicolumn{1}{c}{ Domains } & Mean & $\begin{array}{c}\text { standard } \\
\text { deviation }\end{array}$ & Rank & Degree \\
\hline 2 & Competency attraction & 2.91 & 1.05 & 1 & Medium \\
1 & Creative leadership & 2.78 & .97 & 2 & Medium \\
3 & Job succession & 2.58 & 1.05 & 3 & Low \\
4 & Academic competency retention & 2.56 & 1.01 & 4 & Low \\
Total degree & 2.71 & .96 & - & Medium \\
\hline
\end{tabular}

The results of tale (2) show that the overall mean for the domains of the degree at which administrative leaderships in Tafila Technical University practice the requirements of organizational excellence from the perspective of the faculty members was medium, with a mean of (2.71) and a standard deviation of (0.96). This result could be attributed to the practices of administrative leaderships in the university which prevent achieving the organizational excellence in the university, such as the lack of selection systems that support the plans of leaderships succession to jobs, which doesn't proceed according to the rules that serve the requirements of organizational excellence; indeed, there other considerations which relate to the social pressure and personal relationships, the routine procedures in filling the occupational positions, the lack of qualified competences with regard to the internal attraction, the lack of the plans that satisfy the continuous need for leaders and specialized people in the university departments to ensure the flow of work without interruption, the un clear laws, systems and mechanisms that the university employs in achieving the organizational excellence and maintaining them, the lack of effective incentive system that corresponds with the plans of successive leaderships, as well as the university inability to give incentives that correspond with the needs of the distinguished individuals in order to improve their conditions and acquire their loyalty.

Other reasons are also related to the poor infrastructure needed for organizational excellence, such as the technological aids, training, rehabilitation as well as fear and anxiety related to the change process relating to economic and social reasons, in addition to the long period of time needed for disseminating the culture of change among the university members. The administrative and academic staff is also busy with the existing surrounding problems and the multiple images related to wasting resources, including choosing the non-qualified staff resulting from social pressures as well as the overload administrative staff which doesn't match with the university resources and its work demands and financial resources are also seen as obstacles for organizational excellence. Other reasons could be attributed to the newness of the university, its geographical distance from the capital city of Amman, the lack of services related to excellence schools for the faculty members' children, the lack of health and luxurious services, the lack of career developments programs in the university, in that there are inactive programs in the university, such as the center of developing the faculty members and the center of quality management due to the shortage in the human staff as well as the technical and financial resources.

This finding corresponds with the study conducted by (Dararkeh, 2017) and Qawasmeh and Borini (2016) which was 
of a medium degree, while it contradicts with (Al-Ghamidi, 2018), (Nuweiqah, 2011) and (Majeed, 2010) which was with a high degree, and also contradicts with (Domour, 2017) which was with a low degree.

The domain of attracting scientific competencies was in the first rank with a mean of (2.91) and a standard deviation of (1.05) and a medium degree of practice. This could be attributed to the high financial costs resulting from attracting the academic competencies in the light of the limited financial resources of the university, especially when realize that the university is still new with no more than (20) years old. This result could be attributed to the absence of a clear administrative and academic strategy by the decision makers at the university, which doesn't encourage the academic competencies to stay in the university, as well as the lack of attention to the process of attraction. Also, the administrative leaders at the university could be concerned with the negative impact on the morale of academics working in the university.

The domain related to Academic competency retention was in the last rank and a low degree, with a mean of (2.56) and a standard deviation of (1.01). this finding could be attributed to the fact that maintaining the academic competencies requires financial and morale incentives as well as extra funding which is not available in the university due to the financial crises and due debts. This could also be due to the lack of formal programs concerned with managing and investing the academic competencies in an effective manner in the university. The geographical distance of the university from the center could discourage the qualified academic competencies from coming to the university or continuing in it due to the lack of morale, financial and environmental services that contribute to maintaining these competencies.

\subsection{The Results Pertaining to Second Question}

Which states: Are there any statistically significant differences at $(\alpha \leq 0.05)$ regarding the study sample individuals estimation for the degree at which administrative leaderships in Tafila Technical University practice the requirements of organizational excellence according to the variables of (faculty, academic rank, years of experience)?

In order to answer this question, the researcher calculated the means and standard deviations, t-test and one-way analysis of variance as follows:

\section{A- The differences according to the variable of the faculty:}

In order to detect the statistically significant differences between the mean estimations of the study sample individuals for the degree at which administrative leaderships in Tafila Technical University practice the requirements of organizational excellence from the perspective of the faculty members due to the variable of the faculty, the researcher used t-test to compare between two independent means as illustrated in table (3).

Table 3. T-test for the Impact of Tafila Technical University Practices the Requirements of Organizational Excellence

\begin{tabular}{|c|c|c|c|c|c|c|}
\hline Domains & Scient & ic faculties & Huma & tarian faculties & t-test & \\
\hline & Mean & $\begin{array}{l}\text { Standard } \\
\text { deviation }\end{array}$ & Mean & $\begin{array}{l}\text { Standard } \\
\text { deviation }\end{array}$ & $\mathrm{T}$ & Significance \\
\hline Creative leadership & 2.51 & 1.01 & 3.18 & .76 & 3.691 & .000 \\
\hline Attracting scientific competencies & 2.63 & 1.11 & 3.29 & .82 & 3.325 & .001 \\
\hline Job succession & 2.28 & 1.08 & 3.0 & .83 & 3.774 & .000 \\
\hline Maintaining scientific competencies & 2.28 & 1.04 & 2.92 & .84 & 3.490 & .001 \\
\hline Total degree & 2.43 & 1.01 & 3.1 & 75. & 3.758 & .000 \\
\hline
\end{tabular}

The results of table (3) show that there are statistically significant differences at $(\alpha \leq 0.05)$ regarding the study sample individuals estimation for the degree at which administrative leaderships in Tafila Technical University practice the requirements of organizational excellence according to the variable of faculty in all the domains and total degree. The differences were in favor of the Humanitarian faculties. This finding could be attributed to the case that the faculty members in the Humanitarian faculties have often graduated from national universities, and thus they have no knowledge about the experiences of distinguished international universities. Additionally, the requirements of professional promotion and scientific research don't require equipment and laboratories to do the experiments in comparison with the scientific faculties which require laboratories as well as databases to achieve excellence; however, the needed equipment are not sufficiently available due to the lack of financial resources and the newness of the university. The faculty members of the scientific faculties have often graduated from western universities in 
USA or Europe and have knowledge of the rich experiences of the western universities with regard to organizational excellence. This finding matches with Dmour (2017) which showed that there are differences in favor of the humanitarian faculties.

\section{B- The differences according to the variable of the academic rank:}

In order to detect the statistically significant differences between the mean estimations of the study sample individuals for the degree at which administrative leaderships in Tafila Technical University practice the requirements of organizational excellence from the perspective of the faculty members due to the variable of the academic rank, the researcher used t-test to compare between two independent means as illustrated in table (4).

Table 4. T-test for the Impact of the Academic Rank Variable on the Degree at Which Administrative Leaderships in Tafila Technical University Practice the Requirements of Organizational Excellence

\begin{tabular}{lccccccc}
\hline \multirow{2}{*}{ Domains } & \multicolumn{2}{c}{$\begin{array}{c}\text { Associate professor or } \\
\text { above }\end{array}$} & \multicolumn{2}{c}{$\begin{array}{c}\text { Assistant professor or } \\
\text { less }\end{array}$} & t-test \\
\cline { 2 - 7 } & Mean & $\begin{array}{c}\text { Standard } \\
\text { deviation }\end{array}$ & Mean & $\begin{array}{c}\text { Standard } \\
\text { deviation }\end{array}$ & T & Significance \\
\hline Creative leadership & 2.75 & 1.08 & 2.83 & .80 & .443 & .659 \\
Attracting scientific competencies & 2.80 & 1.15 & 3.04 & .89 & 1.174 & .243 \\
Job succession & 2.60 & 1.08 & 2.55 & 1.01 & .235 & .814 \\
Maintaining scientific competencies & 2.52 & 1.07 & 2.61 & .95 & .447 & .656 \\
Total degree & 2.67 & 1.06 & 2.77 & .83 & .561 & .576 \\
\hline
\end{tabular}

The results of table (4) show that there are no statistically significant differences at $(\alpha \leq 0.05)$ regarding the study sample individuals estimation for the degree at which administrative leaderships in Al-Tafila Technical University practice the requirements of organizational excellence according to the variable of academic rank. This indicates a conversion in perspectives between the faculty members regardless their rank that the degree at which administrative leaderships in Tafila Technical University practice the requirements of organizational excellence is still low and limited, and that there is a weakness with regard to attracting the academic competencies and maintaining them as well as in job succession. This finding matches with Daradkeh, (2017) and Dmour (2017) which showed that there are no differences due to the variable of academic rank.

\section{$C$ - The differences according to the variable of the academic rank:}

In order to detect the statistically significant differences between the mean estimations of the study sample individuals due to the variable of the year of experience, the researcher calculated the means, standard deviations and one-way analysis of variance as shown in table (5).

Table 5. The Means, Standard Deviations for the Study Domains According to the Years of Experience

\begin{tabular}{|c|c|c|c|c|c|c|c|c|}
\hline Domains & \multicolumn{2}{|c|}{ Less than 10 years } & \multicolumn{2}{|c|}{$10-15$ years } & \multicolumn{2}{|c|}{ More than 15 years } & \multicolumn{2}{|c|}{ Total degree } \\
\hline Categories & Mean & $\begin{array}{l}\text { Standard } \\
\text { deviation }\end{array}$ & Mean & $\begin{array}{l}\text { Standard } \\
\text { deviation }\end{array}$ & Mean & $\begin{array}{l}\text { Standard } \\
\text { deviation }\end{array}$ & Mean & $\begin{array}{l}\text { Standard } \\
\text { deviation }\end{array}$ \\
\hline Creative leadership & 2.80 & .93 & 2.65 & 1.05 & 2.95 & .95 & 2.78 & .97 \\
\hline $\begin{array}{l}\text { Attracting scientific } \\
\text { competencies }\end{array}$ & 3.03 & 1.00 & 2.68 & 1.10 & 2.95 & 1.07 & 2.91 & 1.05 \\
\hline Job succession & 2.64 & 1.02 & 2.51 & 1.12 & 2.56 & 1.04 & 2.58 & 1.05 \\
\hline $\begin{array}{l}\text { Maintaining scientific } \\
\text { competencies }\end{array}$ & 2.61 & .93 & 2.39 & 1.10 & 2.70 & 1.08 & 2.56 & 1.01 \\
\hline Total degree & 2.77 & .89 & 2.55 & 1.05 & 2.81 & 1.00 & 2.71 & .96 \\
\hline
\end{tabular}

Table (5) shows that there are apparent differences in the means according to the categories related to the variable of years of experience for the degree at which administrative leaderships in Tafila Technical University practice the requirements of organizational excellence. In order to determine whether the differences between the means are statistically significant at $(\alpha \leq 0.05)$ the researcher used the one-way analysis of variance. Table (6) shows the results. 
Table 6. One-Way Analysis of Variance for the Responses of the Sample Individuals According to the Variable of Experience Years

\begin{tabular}{llccccc}
\hline Domains & Source variance & $\begin{array}{c}\text { Sum of } \\
\text { squares }\end{array}$ & DF & $\begin{array}{c}\text { Mean of } \\
\text { squares }\end{array}$ & F value & $\begin{array}{c}\text { Significance } \\
\text { level }\end{array}$ \\
\hline Creative leadership & Between Groups & 1.242 & 2 & .621 & .650 & .524 \\
& Within Groups & 99.285 & 104 & .955 & & \\
Attracting scientific & Total & 100.527 & 106 & & & .334 \\
competencies & Between Groups & 2.455 & 2 & 1.227 & 1.107 & \\
& Within Groups & 115.304 & 104 & 1.109 & & \\
Job succession & Total & 117.759 & 106 & & & .855 \\
& Between Groups & .355 & 2 & .177 & .157 & \\
Maintaining scientific & Within Groups & 117.110 & 104 & 1.126 & & .481 \\
competencies & Total & 117.465 & 106 & & & \\
& Between Groups & 1.537 & 2 & .768 & .736 & \\
Total degree & Within Groups & 108.539 & 104 & 1.044 & & .520 \\
& Total & 110.076 & 106 & & & \\
& Between Groups & 1.245 & 2 & .623 & .658 & \\
\hline
\end{tabular}

The results of table (6) show that there are no statistically significant differences at $(\alpha \leq 0.05)$ regarding the study sample individuals estimation for the degree at which administrative leaderships in Tafila Technical University practice the requirements of organizational excellence according to the variable of experience years in all the domains. This could be attributed to a conversion in perspectives between the faculty members and their agreement, regardless their experience years, that organizational excellence in the university is away from the employees' ambitions and that the university needs practical procedures in order to achieve the requirements of organizational excellence. This finding matches with Daradkeh, (2017) and Al-Dmour (2017) which showed that there are no differences due to the variable of experience years.

\section{Recommendations}

In the light of the study results, the researcher recommends:

- Providing financial incentives in order to maintain the scientific competencies at the university.

- Providing a safe and attracting university environment for the faculty members that enable them along with their families to stay and continue in the university.

- Activating the mechanisms related to attracting the scientific competencies at the university.

- Determining clear criteria for choosing the academic leaderships at university.

\section{References}

Al-Ghamdi, R. (2018). Organizational Excellence among the female managers of Albaha Schools from the perspective of the female teachers. The International Journal for Educational and Psychological Studies, 3(2), 317-333. https://doi.org/10.12816/0048164

Bakir, Y. (2018). Web metrics Global Classification of Universities. Retrieved 3/1/2019 from https://www.addustour.com/articles/

Dala'een, A. (2010). The Impact of Administrative Empowerment in Organizational Excellence: A Field Study at the Jordanian Telecommunication Company. Administrative Science Studies, 1(37), 64-92.

Daradkeh, A. (2017). Administrative Empowerment and its Relationship with Organizational Excellence among the Academic Leaders of Ta'if University from the Perspective of the Faculty Members. Al-Najah University Journal for Research and Humanities, An-Najah University, 31(8), 1251-1296. 
Dawoud, A. (2011). Quality management and academic accreditation in educational institutions. Kuwait: Al Falah Library for Publishing and Distribution.

Dehaghan, Z., \& Pourtaher, M. (2014). A study on effective factors on organizational excellence based on Booneh and Johnson model: case study Medical Science University of Yasuj, WALIA Journal, 30(S2), 141-146.

Domour, M. (2017). The strategic fitness of academic leaders and its relationship with organizational excellence of the Jordanian universities from the perspective of the faculty members (Unpublished MA). Middle East University, Amman, Jordan.

Grote, D. (2002). The Performance Appraisal Question and Answer Book: A Survival Guide for Managers AMACOM Div. American Mgmt. Assn., United States of America.

Hadi, S. (2013). Change management of Arab higher education institutions towards specific quality and performance excellence. The Arab Journal for Assuring the Quality of University Education, 11, 243-305.

Hamdan, A. (2014). The reality of practicing talent management in the scientific departments at the Faculty of Social Sciences, the University of Imam Mohammad bins So'oud Islamic (Unpublished master thesis). Imam Mohammed University, Al-Riyadh.

Hamidi, M., \& Tayeb, A. (2011). Talent Management and Investment in Training in the $21^{\text {st }}$ Century. a work sheet presented to the first conference of training institutions. Abu Dhabi, the United Arab Emirates. October, 2011.

Hamouda, K., \& Sheikh, R (2013). The management of talents and human competencies. Oman: Zamzam for Publishing.

Harrison, M., McKinnon, T., \& Terry, P. (2006). Effective Succession Planning How to Design and Implement Succession Plan. Training and Development, October, 22-23.

Hassan, A. (2010). The practices of human resources management and their impact on achieving institutional excellence (unpublished master thesis). Middle East University, Amman, Jordan.

Ja'baree, T. (2009). The role of excellence management in developing the performance of higher education institutions in the West Bank (unpublished master thesis). Al-Khaleel University, Palestine.

Kasasbeh, W. (2011). Improving the efficacy of organizational performance using information technology. Jordan, Amman: Al- Yazouri Scientific House.

Khairi, O. (2014). Organizational Excellence. Amman: Dar Al Raya for Publishing and Distribution.

Khrisha, Y., Al-Zoreiqat, K., \& Nour, M. (2013). The impact of change factors on achieving organizational excellence. Arab Potash Company as a model, Management Science Studies, 40(2), 211-238.

Majeed, B. (2010). The Impact of Knowledge Management on Organizational Excellence in the Jordanian Private Universities in the Central Region of Jordan (unpublished Master Thesis). Mu'tah University, Jordan.

Moustafa, S. (2011). Human Resource Management: Individuals' Management (5th ed.). Amman: Dar Al-Shorouq for Publishing.

Nuweiqah, A. (2014). The Impact of Empowering the Work Teams in Achieving Organizational Excellence at Ta'if University-An applied Study. The Jordanian Journal for Business Administration, 3(10), 426-452. https://doi.org/10.12816/0026218

Qawasmeh, F., \& Bourini, F. (2016). Assessing the management practices of university excellence using the European model of excellence from the perspective of the students and staff at Gadara University. The Journal of Business and the Arab Economy, 11(2), 93-104 https://doi.org/10.1016/j.aebj.2016.12.001

Rasheed, S. (2004). Towards building a systematic framework for creativity and business excellence in the Arab organizations. The Fifth Annual Conference in Management, Sharm Al-Sheikh, Egypt, 27-29 November.

Sa'eed, W. (2013). A proposed framework for preparing a second class of administrative leadership as an input to achieve an effective excellence in organizational performance (unpublished $\mathrm{PhD}$ dissertation). Ain Shams University.

Salem, M., \& Saleh, A. (2006). Human Resource Management - A strategic entrance (2nd ed.). Jordan, Irbid: The World of Modern Books for Publishing and Distribution.

Salmi, A. (2002). Management Excellence, models of management and techniques in the age of knowledge. Cairo: Dar Ghraib-for Printing, publishing and distribution. 
Shawwa, E. (2016). The degree at which the managers of public secondary school in the governorate of Gaza to excellence management in the light of the European model of excellence from the perspective of teachers and the methods of developing them (Unpublished master thesis). The Islamic University, Gaza, Palestine.

Shehata, N., \& Hourani, H. (2014). The perceptions of the faculty members at the University of Jordan for the standards of evaluating academic excellence. The Journal of Arab Universities Union in Higher Education, 34(1), 115-129.

Shin, D., Kalinowski, G., \& Abu el-enin, G. (1998). Critical Implementation issues in total quality Management. Advance Management Journal, 1(36), 22-41.

Zo'ubi, A. (2016). The classification of the Jordanian universities witnesses a steady decline since 1996. Retrieved 01/20/2018 from https://www.awa2el.net/ar 